\title{
ANALYTICAL MODELLING OF MASONRY-INFILLED STEEL FRAMES
}

\author{
Ivan Radić, Damir Markulak, Vladimir Sigmund
}

Original scientific paper Masonry itself is a composite heterogeneous material whose structural behaviour is strongly affected by many influencing parameters with a wide range of possible values, construction procedures as well as care methods taken afterwards. When the masonry panel is added into the surrounding frame the complex interactive frame-infill system is established exhibiting highly nonlinear inelastic structural behaviour. Therefore, the analytical modelling of masonry-infilled frame structures is a very complex task that demands various data matching given in-situ conditions, otherwise applied methods and analytical models used have only a theoretical value. In this paper analytical modelling of infilled steel frame structures is based on previously experimentally calibrated data. The base for calibration of analytical models was experimental testing of one-bay, one-storey infilled steel frames conducted at the Faculty of Civil Engineering, Josip Juraj Strossmayer University of Osijek. Two series by three steel frames were infilled with perforated clay blocks ('strong infill') and autoclaved aerated concrete blocks ('weak infill') respectively. The significant difference in structural behaviour of these two kinds of masonry infill is observed and modelled. The macro-models (single-strut and three-strut model and infill-panel macro-model) and detailed 2D micro-models were applied. A total of eight analytical models were analysed with their relevant characteristics along with the quality of representation of the measured global and local results as well as their applicability.

Keywords: analytical modelling of infilled frames; calibration of analytical models; infilled steel frames; masonry infill

\section{Analitičko modeliranje čeličnih okvira sa zidanom ispunom}

Izvorni znanstveni članak

Ziđe je kompozitni heterogeni graditeljski materijal čije konstrukcijsko ponašanje ovisi o mnogim utjecajnim parametrima često s vrlo širokim intervalom mogućih vrijednosti, postupcima izvedbe te primijenjenim metodama njege nakon izgradnje. Ugradnjom zidanog panela u okvirnu konstrukciju uspostavlja se složeni interaktivni sustav okvir-zidani ispun s izrazito nelinearnim neelastičnim ponašanjem. Stoga je analitičko modeliranje ovakvih sustava izuzetno složen zadatak koji zahtijeva usklađivanje potrebnih podataka s in-situ uvjetima, inače primijenjene metode i analitički modeli imaju tek teorijsku vrijednost. U ovom radu je analitičko modeliranje čeličnih okvira sa zidanim ispunom temeljeno na prethodno eksperimentalno kalibriranim podatcima. Osnova za kalibraciju analitičkih modela bilo je eksperimentalno ispitivanje jednokatnih jednorasponskih čeličnih okvira sa zidanom ispunom provedeno na Građevinskom fakultetu Sveučilišta Josipa Jurja Strossmayera u Osijeku. Ispitane su dvije serije po tri čelična okvira ispunjena šupljim glinenim blokovima ("jaki" ispun) odnosno blokovima od porobetona ("slabi" ispun). Zamijećena je i modelirana značajna razlika u konstrukcijskom ponašanju ove dvije vrste zidanog ispuna. Pri modeliranju primijenjeni su makro-modeli (modeli s jednom i tri zamjenske dijagonale te makro-model zidanog panela) te detaljniji ravninski mikro-model. Analizirane su relevantne karakteristike i primjenjivost ukupno osam analitičkih modela iz aspekta kvalitete simulacije izmjerenih globalnih i lokalnih veličina.

Ključne riječi: analitičko modeliranje okvira s ispunom; čelični okviri s ispunom; kalibracija analitičkih modela; zidani ispun

\section{Introduction}

It is a well-known fact by now that masonry infill in frame structures significantly affects its strength, stiffness and ductility causing changes in typical frame behaviour. These changes can be favourable or detrimental, depending on many influencing factors (for example material and geometric properties of structure, structural configuration, load characteristics etc. [1]). The resultant behaviour of the combined structure - the infilled frame is hard to define straightforwardly, and cannot be obtained by mere addition, because of highly non-linear behaviour resulting from ever-changing interaction conditions between the masonry panel and the surrounding frame. Moreover, there is no even common consent on the name of a new structural system, so in the literature one can find terms as "composite", "hybrid", "dual", "combined", "interactive" etc. system.

Furthermore, the fact often pointed out is that neglecting of masonry infill's influence on global and local frame behaviour can seriously affect the reliability of a structure. Structural engineers sometimes tend to ignore contribution of infill panels due to lack of practical design methods, as well as detailed rules for designing of such kind of structures in contemporary codes (such as EC8, [2]). It is therefore understandable a great effort made by various researches to establish simple, but accurate enough approach, of analytical description behaviour of infilled frames. Two main approaches can be distinguished regarding to the masonry infill modelling:

a) macro-modelling: the masonry is treated as homogeneous continuum and there is no distinction between masonry units and joints,

b) micro-modelling: all relevant parts of the masonry infill panel are recognized in the model - masonry units, mortar as well as masonry units-mortar interface.

The first approach has its origins in early research of Polyakov [3], who recognized "truss-like" behaviour of infilled frames, e.g. the possibility to simulate the infill influence by equivalent diagonal compression strut connecting diagonal corners of the frame. The way of modelling masonry infill panel by that simplest macromodel has been substantially improved during the last few decades by virtue of many other researchers [4 $\div 15]$. Despite the reasonably good prediction of global behaviour of infilled frames and wide usage in practice, the main restriction of that method is inability to give insight into local interaction process taking place in areas adjacent to the frame corners. So the next logical step was to encompass those interaction effects into analytical modelling, resulting in models with multiple struts placed at and near the frame corners. There are many various ideas how to calculate characteristics and arrange those struts inside the frame, $[6 \div 21]$. Further advancement in 
analytical modelling was made by using $2 \mathrm{D}$ plane finite elements for infill and so called interface elements for interactive areas between the frame and the infill, [22]. Finite element method offers various powerful tools for creating more realistic analytical models, and therefore it has been widely used (for example $[23 \div 30]$ ).

Permanent striving to simulate as many experimentally observed effects as it is possible finally led to "disassembling" of the infilled frame into its constituent parts (frame elements, masonry units and mortar joints) as well as defining local conditions of their interrelation by appropriate interface elements. That procedure is called micro-modelling and it enables simulation and relevancy assessment of almost each phenomenon inherent in structural behaviour. However, it should be noted that regardless of how detailed and complex models have been created, some important affecting factors usually still stay aside in these, by definition, deterministic analytical models:

- great uncertainty and variation of masonry material properties,

- differences between the laboratory and in situ executed masonry walls/samples

- local construction procedure and care methods taken afterwards, etc.

That fact leads us to the conclusion that probabilistic approach to modelling of the structural behaviour of infilled frames would result in collection and processing of growing experimental and numerical data available, followed by definition and calibration of appropriate resistance models (as it was usual procedure with other types of structures).

In that course the main goal of this paper is to contribute further to the comprehension of structural behaviour of infilled frames, especially from the point of analytical modelling. A critical review of contemporary modelling techniques is presented on the example of previously experimentally tested infilled steel frames [1]. Typical macro and micro models have been created and calibrated using the results of the experimental testing.

\section{Conducted test}

The results obtained by experimental testing of specimens with 'strong' and 'weak' masonry-infill, [1], are considered in this paper. Tested were also constitutive materials' properties on the specimens of the steel frame and masonry infill (masonry units, mortar and masonry wallets). All steel frames were built identical with rigid frame joints and dimensions as shown in Fig. 1.

The specimens $\mathrm{C}-i(i=1 \div 3)$ were three steel frames infilled with perforated clay blocks ('strong' infill with $f_{\mathrm{b}}=11,8 \mathrm{MPa}, f_{\mathrm{m}}=5,0 \mathrm{MPa}$, and $f_{\mathrm{k}}=1,6 \mathrm{MPa}$ ), while the specimens A- $i(i=1 \div 3)$ were three steel frames infilled with Autoclaved Aerated Concrete blocks (AAC) ('weak' infill with $f_{\mathrm{b}}=2,0 \mathrm{MPa}, f_{\mathrm{m}}=9,1 \mathrm{MPa}$, and $f_{\mathrm{k}}=0,9 \mathrm{MPa}$ ), where $f_{\mathrm{b}}$ is the mean normalized vertical compressive strength of masonry unit, $f_{\mathrm{m}}$ is the average compressive strength of mortar and $f_{\mathrm{k}}$ is the mean vertical characteristic compressive strength of masonry.

Detailed data about the tests can be found in [1]. Measured and registered were applied loads at each of the two loading points by load cells, vertical and horizontal displacements of the specimen at the beam and column ends by LVDTs, movement of the foundation beam by LVDTs, elongations of diagonals (on the frame and on the infill) by string potentiometers and local strains at the frame's critical points (column and beam ends) by strain gauges, Fig. 3.

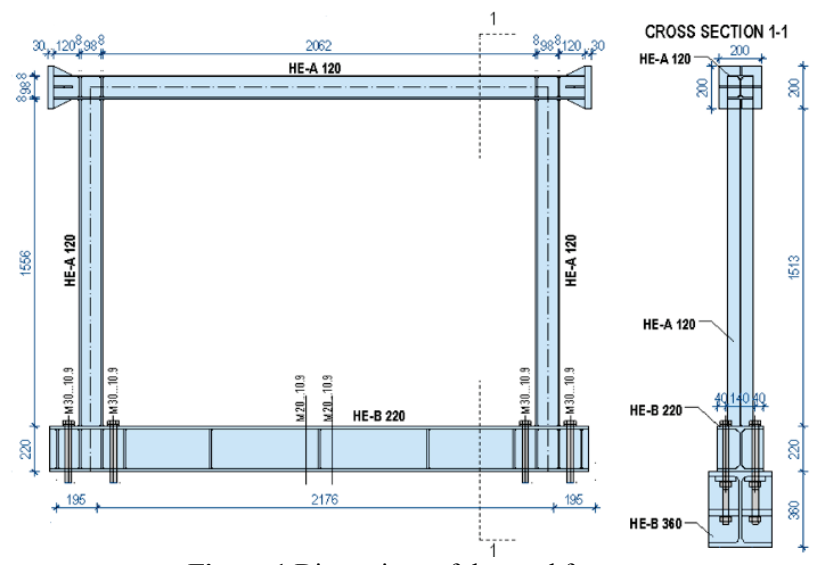

Figure 1 Dimensions of the steel frames



a)

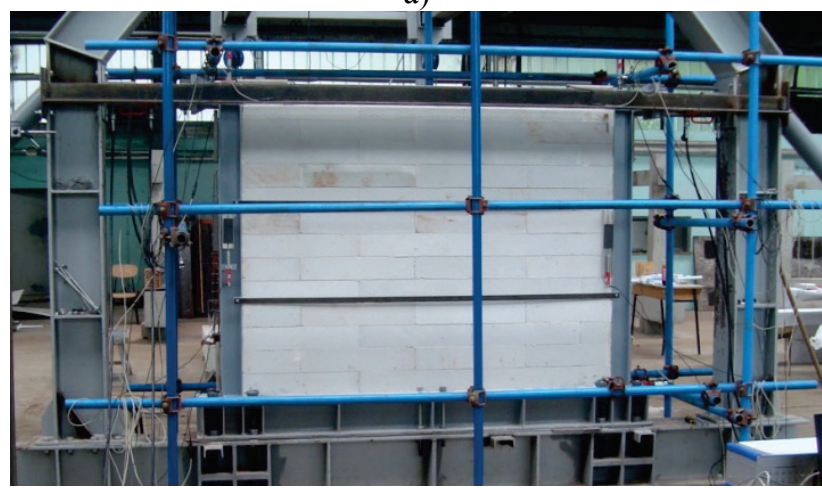

b)

Figure 2 Test set-up for the specimens (a) C-1 and (b) A-1

Experimentally obtained ultimate loads and initial stiffnesses (as the main representatives of the global structural behaviour) of particular specimens are presented in Fig. 4. Regarding the presented results, along with the more detailed comments on it given in [1], significant deviation of the initial stiffness of specimen A1 to that of the other two specimens from that series can be noted. This comment is emphasized because of the calibration process where, for the specimens of A- $i$ series, two average values of the ultimate loads and initial stiffness are given: the total average value (from all three 
specimens) and appropriate values calculated for specimens A-2 and A-3 only.
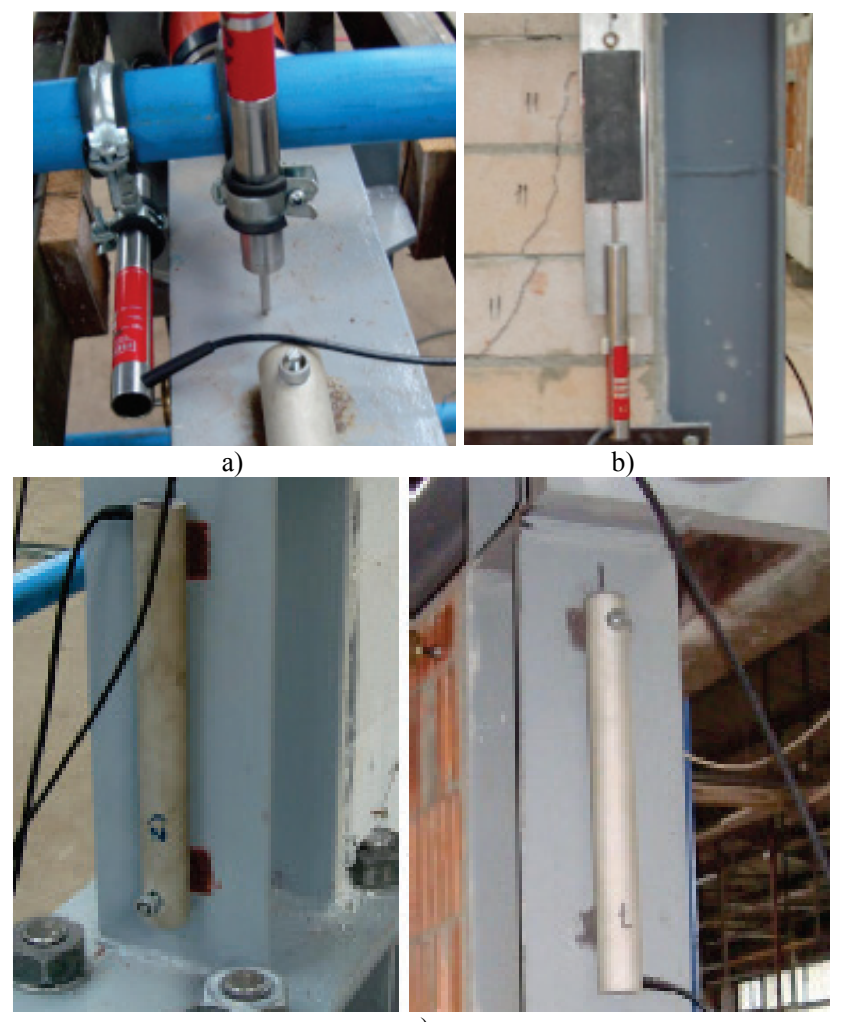

c)

Figure 3 Some of parameters measured during testing - a) horizontal and vertical displacements of the specimens, b) elongation of diagonals, c) strains at the frame critical points



Figure 4 Ultimate load and initial stiffness of bare steel frame (BF), frames infilled with perforated clay blocks $(\mathrm{C}-i)$ and AAC blocks (A-i)

\section{Analytical modelling by use of macro-models}

Physically intuitive approach of simulating the masonry action by an equivalent diagonal compression strut is the basic concept of macro-modelling. Its main advantages are the simple modelling (that does not require any specialized software nor type of the finites elements), small number of control parameters for its calibration along with reasonably good representation of the global behaviour. However, if those models are subjected to cycling, alternate load actions (for example earthquake excitation) time required for calculation significantly increases since the effectiveness of diagonal struts in compression only has to be taken into account. The next restriction of the single strut model is its inability to realistically present distribution of bending moments and shear forces in the frame elements. Consequently, very important phenomena like short column effect or large localized shear deformations of column web near the frame joints cannot be covered by this model. Those and similar interaction effects can be anticipated by multiple strut models. All those models with compression diagonal struts conceptually rely on the compression strength of the infill, while the influence of horizontal shear sliding stays neglected. Because of the significant strength and stiffness degradation of the system, when exposed to cyclic loads, commonly used elastic or elastic-ideal plastic material models are not applicable for masonry infilled frames.

Above mentioned facts can be, up to a certain extent, included into macro-models by the "nonlinear hinge". The nonlinear-hinge enables introduction of discrete nonlinearity defined by the lateral force-deformation relationship that simulates the behaviour of the masonry infill, Fig. 5b. That curve is usually polygonal and represents the masonry infill's strength envelope with key points calculated on the basis of infill properties. Those points signify typical working phases of the masonry infill - elastic domain, yielding zone with gradual stiffness degradation, post-peak strong stiffness degradation area and finally residual strength level, Fig. 5c. The advantage of this approach is that different modes of infill's failure can be represented, but the inability of taking into account the effects of interaction still remain.

\subsection{Model with single equivalent strut}

The nonlinear single strut model (SSM), used in this paper, is shown in Fig. 5 and it includes discrete nonlinear hinge which describes behaviour of masonry infill.

The analytical models of the two tested specimens' series have been created in Autodesk Robot Structural Analysis software package [31]. The steel frame material was modelled as elastic-ideal plastic with yield strength $f_{y}=337 \mathrm{~N} / \mathrm{mm}^{2}$ and modulus of elasticity $E_{s}=210000$ $\mathrm{N} / \mathrm{mm}^{2}$, according to the test results, [1]. The appropriate representative properties of masonry infill used for defining characteristics of equivalent diagonal strut were obtained on the masonry wallets [1]. Thus, the modulus of elasticity $\left(E_{m}\right)$ and shear strength $\left(f_{\mathrm{vk}}\right)$ of $\mathrm{C}-i$ specimens were $4600 \mathrm{~N} / \mathrm{mm}^{2}$ and $0,227 \mathrm{~N} / \mathrm{mm}^{2}$ respectively, while the appropriate characteristics of $\mathrm{A}-i$ specimens were $1200 \mathrm{~N} / \mathrm{mm}^{2}$ and $0,240 \mathrm{~N} / \mathrm{mm}^{2}$. Required properties of the equivalent diagonal strut, representing elastic in-plane stiffness of masonry infill, were obtained by use of the well-known expressions [32]:

$$
\begin{aligned}
& b_{w}=0,175 \cdot\left(\lambda \cdot h_{c}\right)^{-0,4} \cdot r_{w}, \\
& \lambda=\left[\frac{E_{m} \cdot t_{w} \cdot \sin 2 \theta}{4 E_{s} \cdot I_{c o l} \cdot h_{w}}\right]^{\frac{1}{4}},
\end{aligned}
$$

where, along with already defined notations, $h_{c}$ and $h_{w}$ are the steel column and the masonry infill panel height, respectively, $r_{w}$ is the clear diagonal length of the infill panel, $I_{c o l}$ is the moment of inertia of the steel column, $\theta$ is the inclination of the diagonal strut with respect to the horizontal plane, $t_{w}$ is the thickness of the infill panel, and 
$\lambda$ is coefficient used to determine the equivalent width of diagonal strut.

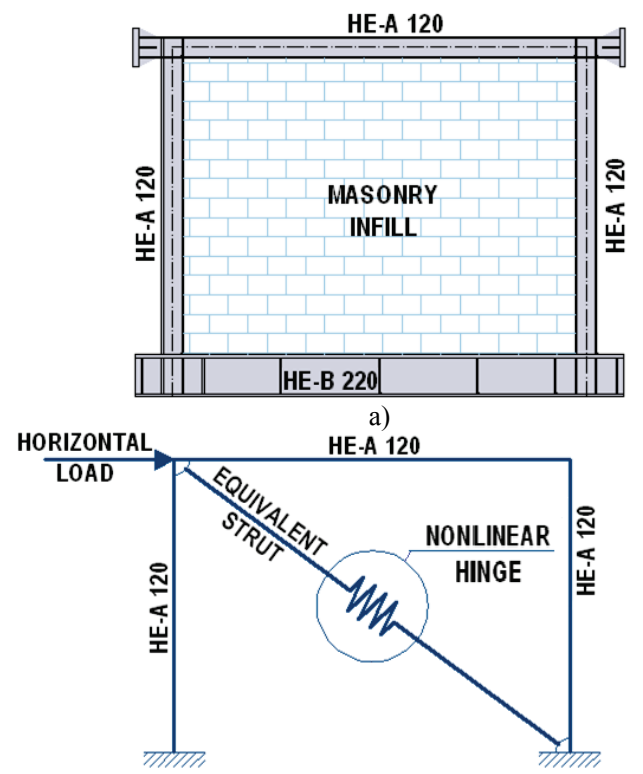

b)

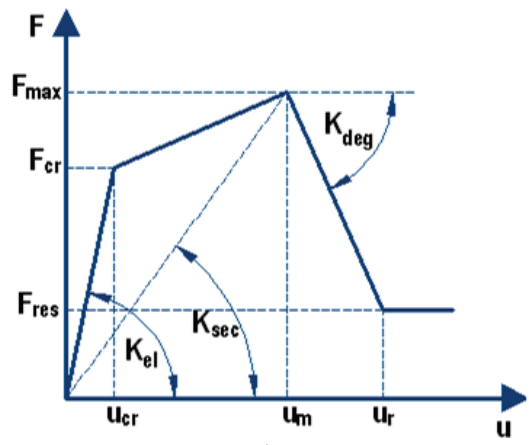

c)

Figure 5 Non-linear single strut model

The procedure for determining the key points of the envelope curve, Fig. 5c, is often described in the literature (for example [33] or [34]) and there is no need to repeat it here. However, it is worth to mention that two critical failure modes - sliding shear and compression failure are taken into account for estimating the maximum lateral strength, $F_{\text {max. }}$ Relationships between relevant points of the infill envelope curve in the form suitable for the calibration process can be presented as follows:

$F_{\text {max }}=k_{1} \cdot F_{\text {cr }}$,

$F_{\text {res }}=k_{2} \cdot F_{\text {max }}$,

$K_{\mathrm{sec}}=\frac{E_{m e} \cdot b_{w} \cdot t_{w}}{r_{w}} \cdot \cos ^{2} \theta$

$K_{\mathrm{deg}}=\alpha \cdot K_{\mathrm{el}}$,

where:

$F_{\text {cr }}$ - shear force at yielding,

$F_{\text {res }}$ - post-peak residual shear force,

$K_{\mathrm{el}}-$ initial stiffness of the infill panel,

$K_{\text {sec }}$ - secant stiffness (targets at the maximum strength),

$K_{\text {deg }}-$ stiffness corresponding to the post-peak degrading branch of the envelope,

$\alpha$ - the ratio of the post- to pre-yield stiffness,

$k_{1}, k_{2}$ - coefficients that depend on infill properties.



a)



b)

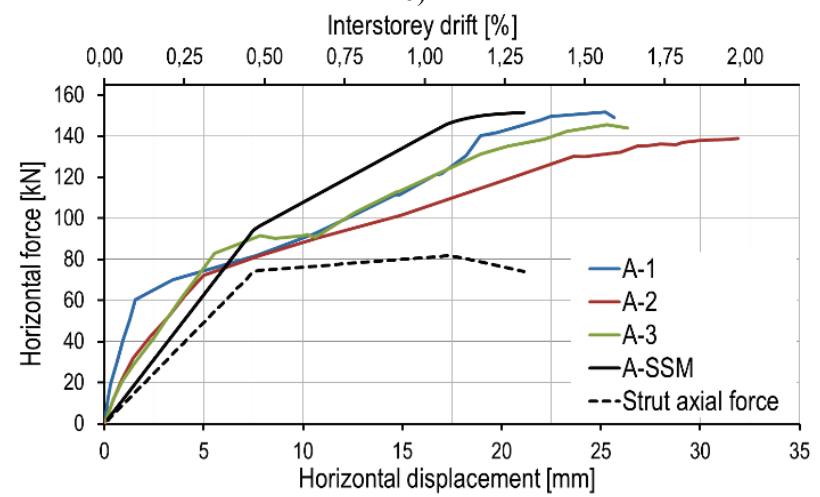

c)

Figure 6 Comparisons of analytical (SSM model) and experimental results, (a) average ultimate lateral load and initial stiffness, (b) and (c) experimental hysteresis envelopes and analytical results for $\mathrm{C}-i$ series and A- $i$ specimens respectively

In the literature various values as estimate of the parameters $k_{1}, k_{2}$ and $\alpha$ have been given. Very often they either correspond to the very specific conditions or their range of values is quite wide. For example, in the paper [33] the value of 1,30 is suggested for the coefficient $k_{1}$, while the range of values for $\alpha$ is between 0,005 and 0,1 (upper value corresponds to the very brittle infill). In the same manner, the value of 0,30 is proposed for $k_{2}$ in [32]. So, proposed values can serve for the approximate estimate of the structural behaviour of infilled frames, but the need of relevant experimental data that represent particular properties/conditions is obvious for the practical design.

In this paper the calibration of parameters $k_{1}, k_{2}$ and $\alpha$ for all three tested series of the specimens has been done. The obtained values of parameters $k_{1}$ and $\alpha$ for $\mathrm{C}-i$ specimens were 1,30 and 0,01 respectively, while for A- $i$ specimens these values were 1,10 and 0,03 . For both series the value of 0,30 was adopted for parameter $k_{2}$. 
Other calibrated parameters of the infill's strength envelope curves are presented in Tab. 1.

Graphical comparisons of the analytical SSM model results with the appropriate experimental results (presented in the form of hysteresis envelopes) from [1] are presented in Fig. 6. In order to additionally emphasize contribution to the structural behaviour of particular type of infill, calculated force in the diagonal strut is separately shown.

Table 1 Parameters of infill strength envelopes for the single strut models (SSM)

\begin{tabular}{|c|c|c|c|c|c|c|c|c|c|c|c|}
\hline Model & $\lambda$ & $\begin{array}{c}b_{w} \\
(\mathrm{~mm})\end{array}$ & $\begin{array}{c}K_{\mathrm{el}} \\
(\mathrm{kN} / \mathrm{mm})\end{array}$ & $\begin{array}{c}K_{\mathrm{sec}} \\
(\mathrm{kN} / \mathrm{mm})\end{array}$ & $\begin{array}{c}K_{\mathrm{deg}} \\
(\mathrm{kN} / \mathrm{mm})\end{array}$ & $\begin{array}{c}F_{\mathrm{cr}} \\
(\mathrm{kN})\end{array}$ & $\begin{array}{l}F_{\max } \\
(\mathrm{kN})\end{array}$ & $\begin{array}{c}F_{\text {res }} \\
(\mathrm{kN})\end{array}$ & $\begin{array}{c}u_{c r} \\
(\mathrm{~mm})\end{array}$ & $\begin{array}{c}u_{m} \\
(\mathrm{~mm})\end{array}$ & $\begin{array}{c}u_{r} \\
(\mathrm{~mm})\end{array}$ \\
\hline C-SSM & 0,00286 & 245,21 & 292,60 & 33,39 & 2,93 & 70,37 & 91,48 & 27,44 & 0,240 & 2,740 & 24,625 \\
\hline A-SSM & 0,00204 & 280,48 & 76,33 & 9,96 & 2,29 & 74,40 & 81,84 & 24,55 & 0,975 & 8,215 & 33,231 \\
\hline
\end{tabular}

\subsection{Model with three equivalent struts}

The analytical model with three equivalent strut diagonals, developed by El-Dakhakhni [21] was chosen as representative for multiple struts models. The contact areas between the frame and the infill panel are of particular concern in this model, and according to [21] in the case of steel frames infilled with masonry infill the contact lengths are located at following distances from the beam-column connections, Fig. 7:

$$
\begin{aligned}
& \alpha_{c} \cdot h_{c}=\sqrt{\frac{2\left(M_{p j}+0,2 M_{p c}\right)}{f_{m-0}^{\prime} \cdot t_{w}}} \leq 0,4 h_{c}, \\
& \alpha_{b} \cdot l_{b}=\sqrt{\frac{2\left(M_{p j}+0,2 M_{p b}\right)}{f_{m-90}^{\prime} \cdot t_{w}}} \leq 0,4 l_{b},
\end{aligned}
$$

where, $\alpha_{\mathrm{c}}$ is the ratio of the column contact length to the height of the column $h_{\mathrm{c}}, \alpha_{\mathrm{b}}$ is the ratio of the beam contact length to span of the beam $l_{\mathrm{b}} ; M_{p j}$ is the minimum of the column, beam or connection's plastic moment capacity; $M_{p c}$ and $M_{p b}$ are the column and beam's plastic moment capacities, respectively; $f_{m-0}$ and $f_{m-90}$ are the compressive strength of the masonry panel parallel and normal to the bed joint, respectively, and $t_{w}$ is the infill thickness. It is worth noting that the influence of actual steel joint behaviour can also be taken into account by use of the above expressions.

In this approach the single strut model is improved by addition of two other equivalent struts on each side of the central diagonal strut, Fig 7. These struts connect corresponding beam and column and their ends are placed at the edges of the contact lengths calculated according to expressions (7) and (8).

The total diagonal struts area is to be calculated by:

$$
A=\frac{\left(1-\alpha_{c}\right) \cdot \alpha_{c} \cdot h_{c} \cdot t_{w}}{\cos \theta}
$$

where $\theta$ is an angle defining inclination of the central strut. The total area should be divided in a way that the central strut is half of the area and each of the other two struts has one quarter of the whole area.

Since masonry panel is strongly heterogeneous structural element, it is treated as an orthotropic plate with the modulus of elasticity $E_{0}$ and $E_{90}$ in the direction parallel and normal to the bed joints respectively. As the lateral load acts at the frame joints, it is transferred by infill panel's diagonal action and characteristics of the panel in diagonal direction ought to be calculated, [35]:

$$
\begin{aligned}
& \frac{1}{E_{\theta}}=\frac{\cos ^{4} \theta}{E_{0}}+\frac{\sin ^{4} \theta}{E_{90}}+\frac{\cos ^{2} \theta \cdot \sin ^{2} \theta}{\left(\frac{E_{90}}{E_{0}} \frac{E_{90}}{E_{0}}\right) 0,2 \cdot \sqrt{E_{0} \cdot E_{90}}}, \\
& f_{m-\theta}^{\prime}=\frac{E_{\theta} \cdot f_{m-90}^{\prime}}{E_{90}},
\end{aligned}
$$

where, $E_{\theta}$ is the modulus of elasticity in diagonal direction; $f_{m-\theta}^{\prime}$ and $f_{m-90}^{\prime}$ are the ultimate strength of the masonry infill in $\theta$ and normal to the bed joints direction, respectively.

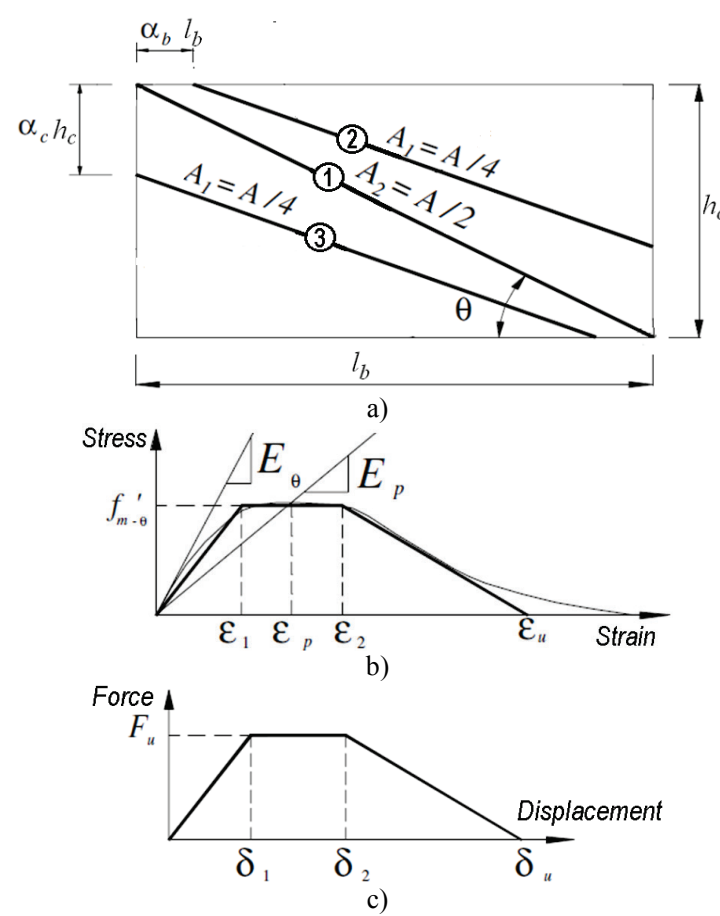

Figure 7 Multiple strut model (MSM), (a) Model layout, (b) Simplified tri-linear stress-strain relationship for masonry infill, (c) typical forcedeformation relationship for the struts

Although model allows more influential parameters to be included, its accuracy model is strongly influenced by the availability of relevant material and elements properties. More sophisticated models demand the more detailed data. Use of tri-linear stress strain relationship instead of the actual parabolic relationship is suggested in [21], Fig. 7b. Peak load secant stiffness of the infill frames is to be taken as half of the initial stiffness, i.e. $E_{p}=0,5 E_{\theta}$, according to [20]. Thus, knowing $E_{p}$ and $f_{m-\theta}^{\prime}$ it 
is easy to determine the strain corresponding to the peak load, $\varepsilon_{p}$. Other relevant parameters for definition of the primary curve, as suggested in [21], in the absence of more accurate data can be assumed as follows:

$$
\begin{aligned}
& \varepsilon_{1}=\varepsilon_{p}-0,001 \\
& \varepsilon_{2}=\varepsilon_{p}+0,001, \\
& \varepsilon_{u}=0,01
\end{aligned}
$$

By use of our own experimental data and Eqs. (7) : (12), the strength envelope for the three strut model (MSM) is defined and shown in Tab. 2.

Calculated calibrated values for $\varepsilon_{1}$ and $\varepsilon_{2}$ strains given in Eq. (12) for specimens with perforated clay bricks (CMSM) and with AAC blocks (A-MSM) were $\varepsilon_{p} \pm 0,0005$ and $\varepsilon_{p} \pm 0,0018$ respectively, while the value of $\varepsilon_{u}$ for both series was 0,01 .

In Fig. 8 the comparisons of the MSM analytical model results with the appropriate experimental results are given in the same graphic form as for the single strut

\begin{tabular}{|c|c|c|c|c|c|c|c|c|c|c|}
\hline \multirow{2}{*}{ Model } & \multirow{2}{*}{$\begin{array}{c}E_{\theta} \\
\left(\mathrm{N} / \mathrm{mm}^{2}\right)\end{array}$} & \multirow{2}{*}{$\begin{array}{c}f_{m-\theta}^{\prime} \\
\left(\mathrm{N} / \mathrm{mm}^{2}\right)\end{array}$} & \multicolumn{4}{|c|}{ External struts } & \multicolumn{4}{|c|}{ Central strut } \\
\hline & & & $F_{u}(\mathrm{kN})$ & $\delta_{1}(\mathrm{~mm})$ & $\delta_{2}(\mathrm{~mm})$ & $\delta_{u}(\mathrm{~mm})$ & $F_{u}(\mathrm{kN})$ & $\delta_{1}(\mathrm{~mm})$ & $\delta_{2}(\mathrm{~mm})$ & $\delta_{u}(\mathrm{~mm})$ \\
\hline C-MSM & 4399 & 1,91 & 27,82 & 0,672 & 2,491 & 18,190 & 55,65 & 1,001 & 3,710 & 27,090 \\
\hline A-MSM & 1147 & 1,16 & 16,83 & 0,362 & 6,374 & 16,700 & 33,67 & 0,587 & 10,339 & 27,090 \\
\hline
\end{tabular}
model.

Table 2 Parameters of the strength envelope for three struts model (MSM)

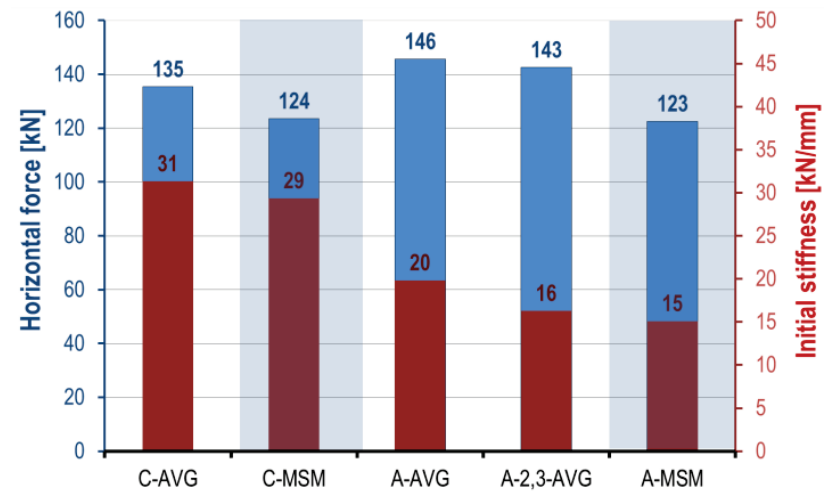

a)

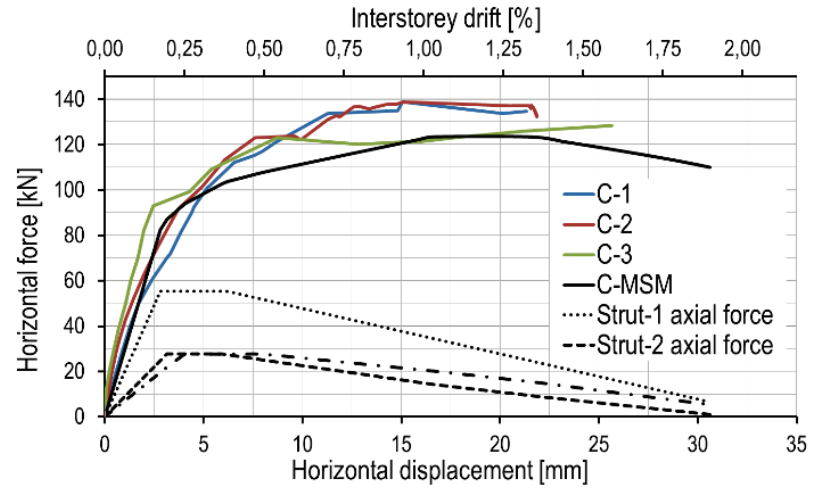

b)

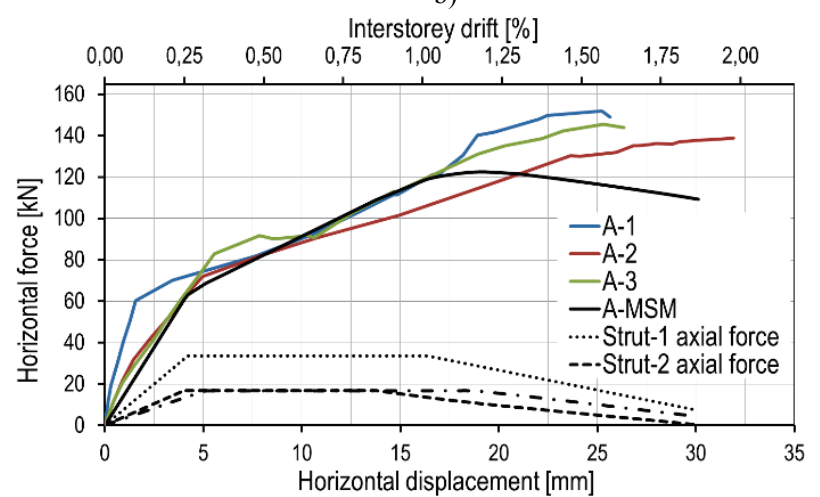

c)

Figure 8 Comparisons of the analytical (MSM model) and experimental results, (a) average ultimate lateral load and initial stiffness, (b) and (c) experimental hysteresis envelopes and analytical results for $\mathrm{C}-i$ series and specimens A- $i$ respectively

\subsection{Model with the infill panel element macro model}

Very efficient way to simplify and accelerate the process of infill modelling is use of the predetermined finite element panel available in some FEM packages. In this paper the inelastic infill panel element ('infill') implemented in Seismostruct software [36] has been used. The behaviour of that element is based on research carried out by Crisafulli and Carr [37] and Crisafulli [38], and is capable for describing the most common modes of failure - diagonal compression mode and sliding shear mode. Inclusion of all types of masonry failure modes would not be practical due to complexity and uncertainty of the problem.

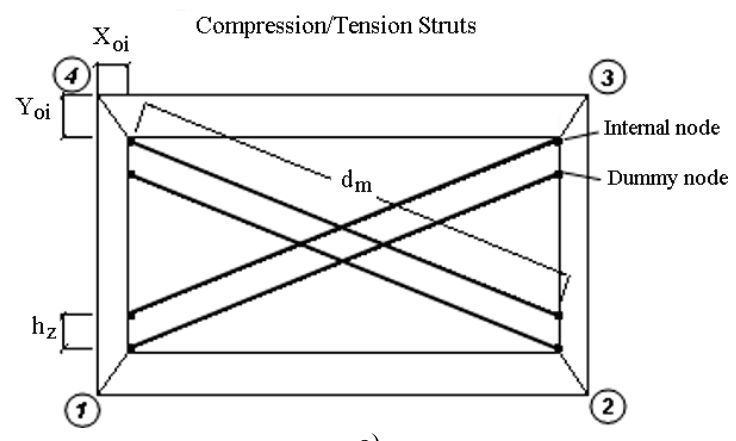

a)



b)

Figure 9 Infill element, (a) Compression/Tension struts, (b) Shear strut

An infill panel is represented by six strut members each diagonal direction is modelled with two parallel struts that take over diagonal axial loads while the third one carries the shear (in each direction as well), Fig. 9.

Although four dummy nodes are introduced with the intention of taking into account the interactive contact length between the frame and the infill panel, in the end 
all internal forces are transferred to the four corner nodes of the frame.

The masonry strut hysteresis model has been used for definition of the axial load struts, while the shear strut uses a bilinear hysteresis rule. Complete definition of the inelastic response curve for axial struts is more complex and requires seventeen parameters to be assigned, as opposed to four parameters needed for the shear strut.
Besides common mechanical properties of the masonry infill subjected to axial and/or shear stresses, there are also empirical parameters related to cyclic loading. The model allows for reduction of equivalent strut area due to cracking as well as definition of the equivalent contact length between the frame and the infill panel. The other details of the model can be found in [36].

Table 3 Relevant parameters of the models with predetermined macro-element (SPM)

\begin{tabular}{|c|c|c|c|c|c|c|c|c|c|c|c|}
\hline Model & $\begin{array}{c}b_{w} \\
{[\mathrm{~mm}]}\end{array}$ & $\begin{array}{c}A_{l} \\
{\left[\mathrm{~mm}^{2}\right]}\end{array}$ & $\begin{array}{c}A_{2} \\
{\left[\mathrm{~mm}^{2}\right]}\end{array}$ & $\begin{array}{c}h_{z} \\
{[\%]}\end{array}$ & $\begin{array}{c}E_{m} \\
{\left[\mathrm{~N} / \mathrm{mm}^{2}\right]}\end{array}$ & $\begin{array}{c}f_{m \theta} \\
{\left[\mathrm{N} / \mathrm{mm}^{2}\right]}\end{array}$ & $\begin{array}{c}f_{t} \\
{\left[\mathrm{~N} / \mathrm{mm}^{2}\right]}\end{array}$ & $\begin{array}{c}\varepsilon_{m} \\
{[-]}\end{array}$ & $\begin{array}{c}\varepsilon_{u l t} \\
{[-]}\end{array}$ & $\begin{array}{c}c \\
{\left[\mathrm{~N} / \mathrm{mm}^{2}\right]}\end{array}$ & $\begin{array}{c}\mu \\
{[-]}\end{array}$ \\
\hline C-SPM & 245 & 29424 & 26482 & 14,12 & 4600 & 1,39 & 0,22 & 0,0012 & 0,01 & 0,70 & 0,80 \\
\hline A-SPM & 281 & 33658 & 30292 & 19,75 & 1200 & 1,02 & 0,24 & 0,002 & 0,08 & 0,30 & 0,35 \\
\hline
\end{tabular}
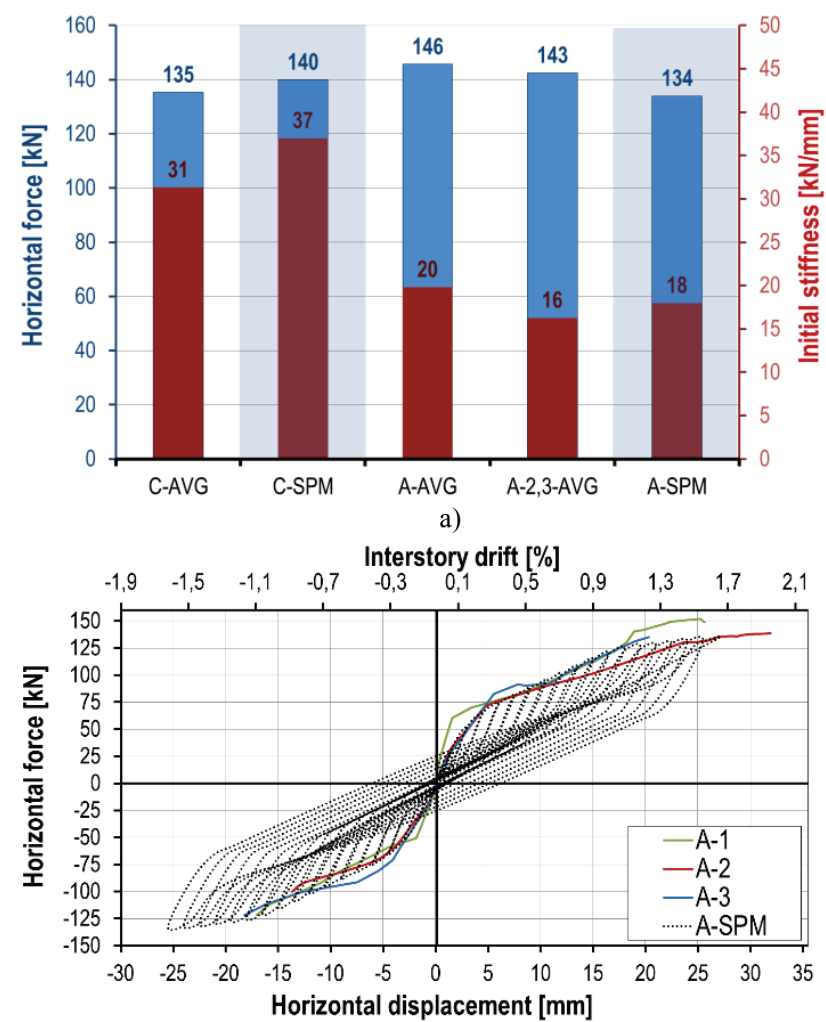

b)



c)

Figure 10 Comparisons of the analytical (SPM model) and experimental results, (a) average ultimate lateral load and initial stiffness, (b) and (c) experimental hysteresis envelopes and analytical results for $\mathrm{C}-i$ series and A- $i$ specimens respectively

According to [36], the compressive strength of the infill panel for specimens $\left(f_{m \theta}\right)$ infilled with perforated clay blocks $(\mathrm{C}-i)$ was defined as the lowest value of the most probable failure mechanism ((1) diagonal tension,
(2) sliding shear, (3) corner crushing and (4) diagonal compression) and obtained experimental data, [1]:

- the shear resistance under diagonal compression $f_{w s}=0,22 \mathrm{~N} / \mathrm{mm}^{2}$,

- the sliding shear resistance of the mortar joints $f_{w u}=0,63 \mathrm{~N} / \mathrm{mm}^{2}$,

- the fundamental compression resistance $f_{w}^{\prime}=2,0$ $\mathrm{N} / \mathrm{mm}^{2}$.

The appropriate values for specimens infilled with AAC blocks $(A-i)$ were $f_{w s}=0,24 \mathrm{~N} / \mathrm{mm}^{2}, f_{w u}=0,30 \mathrm{~N} / \mathrm{mm}^{2}$ and $f^{\prime}{ }^{\prime}=1,21 \mathrm{~N} / \mathrm{mm}^{2}$.

The steel frame behaviour was modelled by the uniaxial Menegotto - Pinto steel model yield strength $f_{\mathrm{y}}=337 \mathrm{~N} / \mathrm{mm}^{2}$ and modulus of elasticity $E_{s}=210000$ $\mathrm{N} / \mathrm{mm}^{2}$. Based on above assumptions, the appropriate macro-models (SPM) of each tested series have been created. The relevant parameters defining the behaviour of panel infill macro-element are listed in Tab. 3.

The most important parameters that influenced the calibration process were the infill's modulus of elasticity $\left(E_{m}\right)$, reduced area of the equivalent strut $\left(A_{2}\right)$, compressive strength $\left(f_{m \theta}\right)$ with appropriate strain $\left(\varepsilon_{m}\right)$ as well as shear strength expressed by the initial shear bond strength $(c)$ and coefficient of friction $(\mu)$.

Fig. 10 shows comparisons between the experimental and analytical results, obtained for the SPM model.

\section{Analytical modelling by use of micro-models}

As it was mentioned earlier, micro-modelling implies simulation of the structural behaviour in detail, by considering each constitutive structural material separately and taking into account their inter-relations. Detailed analytical simulation of an infilled frame structural behaviour requires a great number of influencing factors that affect masonry panel, surrounding frame and frame-panel interactions. While modelling of the frame is more or less common engineering task, the problem of an appropriate representation of the masonry infill and frame-masonry panel interface conditions requires much more effort and skill.

Opposed to the consideration of the masonry infill as homogeneous continuum, e.g. one phase material in the macro-modelling approach, detailed micro-modelling technique is based on masonry infill as two or threephases material. Simplified micro-modelling comprises two-phases material model, e.g. it regards the masonry 
units as the first, and the mortar joints together with the unit-mortar interface as the second constitutive part of the masonry panel. Differentiation of all three main parts of the infill panel (units, mortar joints and units-mortar interface) is employed in detailed micro-modelling procedure. Besides the appropriate representation of the masonry infill, the accuracy of the analytical model is in great deal affected by the adequate description of the boundary conditions at panel-frame interfaces. In general, the contact area between the frame and the infill panel can be modelled by either the so-called tie-link or interface elements. Their purpose is to allow possible deformations, sliding and separation along the contact area. Tie-link element represents discrete modelling of those conditions at the level of two adjacent nodes of panel and frame. Use of the interface elements provides more accurate representation of the contact area based on various constitutive relationships (e.g. Coulomb's friction theory).

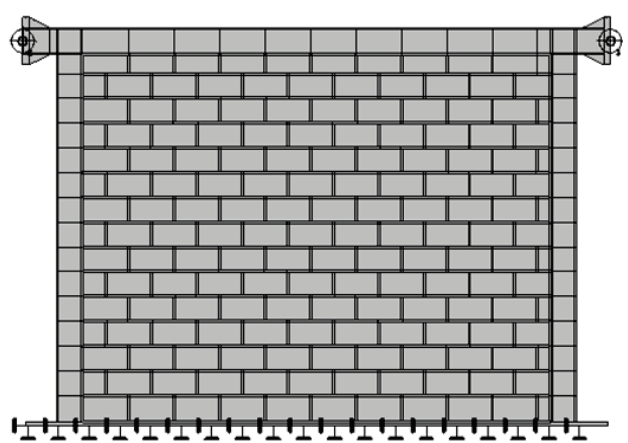

a)

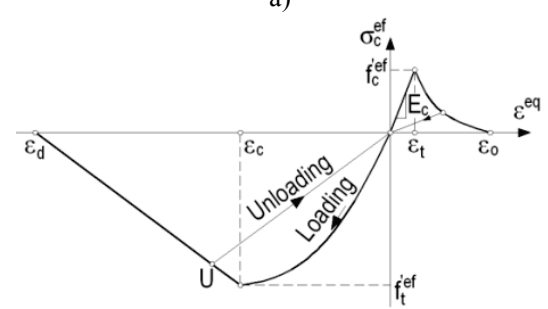

b)



c)

Figure 11 Micromodel (AMM), (a) Model layout (b) SBETA material model, (c) Mohr-coulomb criterion for interface elements

Micro-modelling of the infilled steel frames in this paper has been done with the ATENA 2D FEM package, [39, 40]. Detailed approach with three-phase masonry model was used. Masonry units were modelled by the material model SBETA that includes the non-linear behaviour in compression, fracture in tension based on the nonlinear fracture mechanics, reduction of compressive strength as well as the shear stiffness after cracking and various crack models, Fig. 11b. Although originally created for simulating the concrete behaviour, this model proved to be applicable for modelling of the brick masonry. Plane quadrilateral finite elements with nine nodes and plane triangular finite elements with six nodes were used for modelling, Fig. 11a. The model for the interface material is based on the Mohr-Coulomb criterion with tension cut off, Fig. 11c. The interface is defined by a pair of parallel lines, each located on the opposite side, and can share the same position in un-deformed geometry. Special care was paid to assignment of the initial elastic normal and shear stiffness of those elements, as they greatly influence the accuracy and numerical stability.

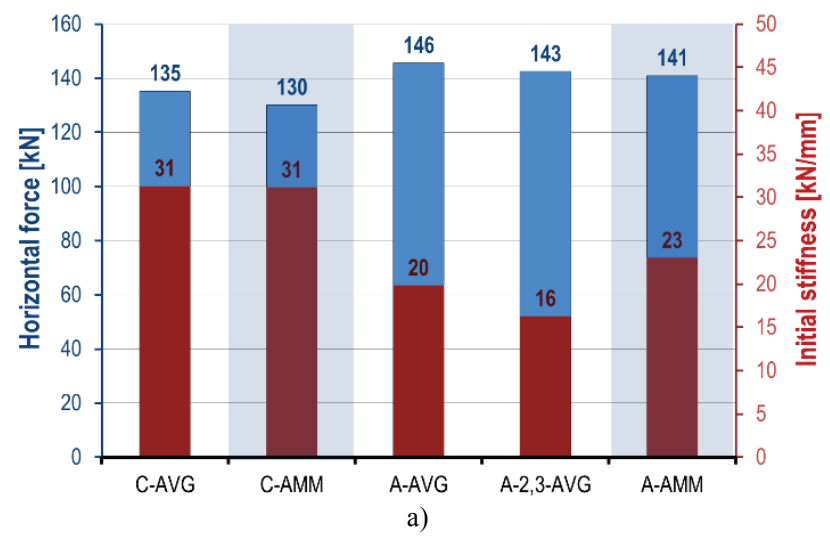
Interstory drift [\%]

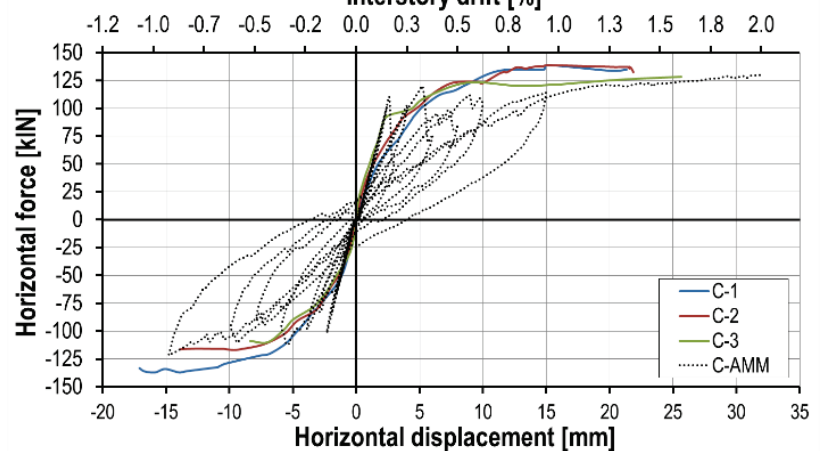

b)



c)

Figure 12 Comparisons of analytical (AMM model) and experimenta results, (a) average ultimate lateral load and initial stiffness, (b) and (c) experimental hysteresis envelopes and analytical results for $\mathrm{C}-i$ series and $\mathrm{A}-i$ specimens respectively

Two types of interface elements were created - the first type for mortar joints in masonry panel and the second type for contact line between the frame and the infill. Relevant mechanical characteristics of the steel frame and masonry infill materials used in analytical micro-models (AMM) are given in Tab. 4.

Calibrated values of the cohesion $(c)$ for interface elements of the first type were from 0,20 to $0,60 \mathrm{~N} / \mathrm{mm}^{2}$, while the range of the tensile strength $\left(f_{t}\right)$ was $0,20 \div 0,30$ $\mathrm{N} / \mathrm{mm}^{2}$. The appropriate values for the second type were 
from 0,01 to $0,12 \mathrm{~N} / \mathrm{mm}^{2}$ and from 0,01 to $0,10 \mathrm{~N} / \mathrm{mm}^{2}$, for $c$ and $f_{t}$ respectively.

Comparison of the analytical (AMM models) and experimental results for tested series of specimens is given in Fig. 12. Micro-modelling enables much more detailed insight into the structural behaviour than macromodelling, so that distribution of the normal and shear stresses both at $0,5 \%$ interstory drift and at failure as well as crack pattern comparisons for both tested series are given in Fig. 13 to 18 .



a)
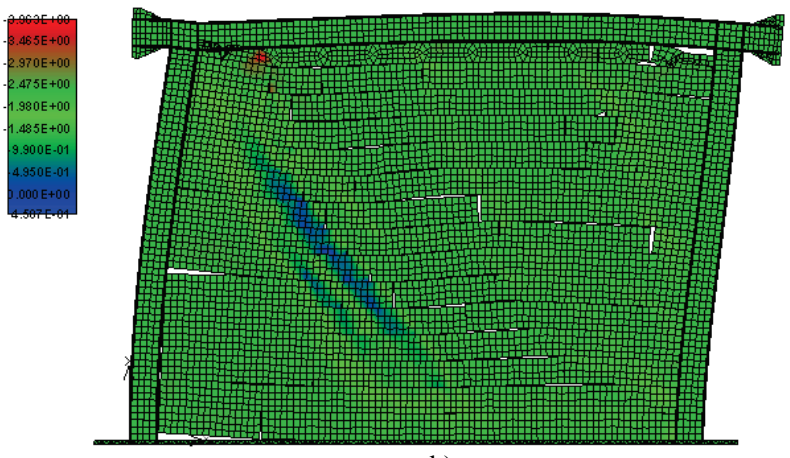

b)

Figure 13 Stress distribution in C-AMM model at 0,5 \% interstory drift ratio: (a) normal stress, (b) shear stress

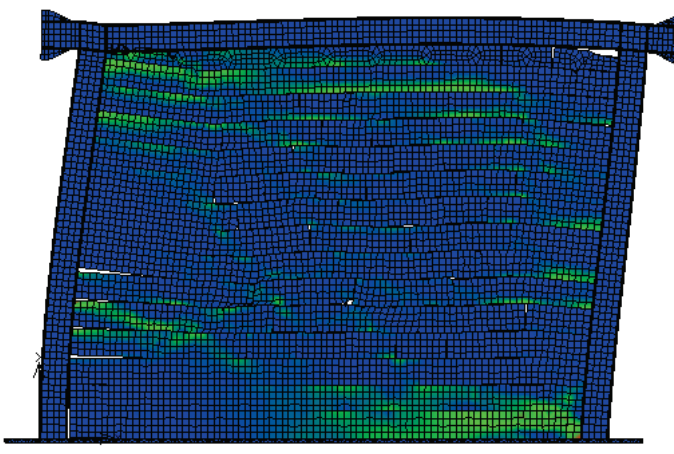

a)



a)
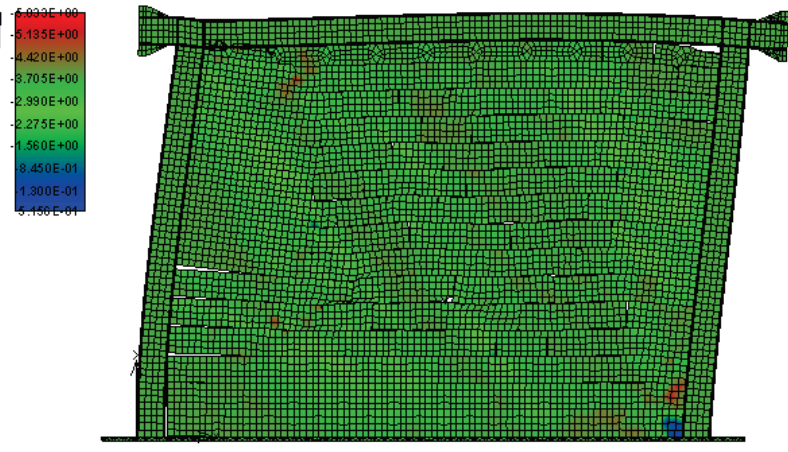

b)

del at failure: (a) normal stress, (b) shear stress

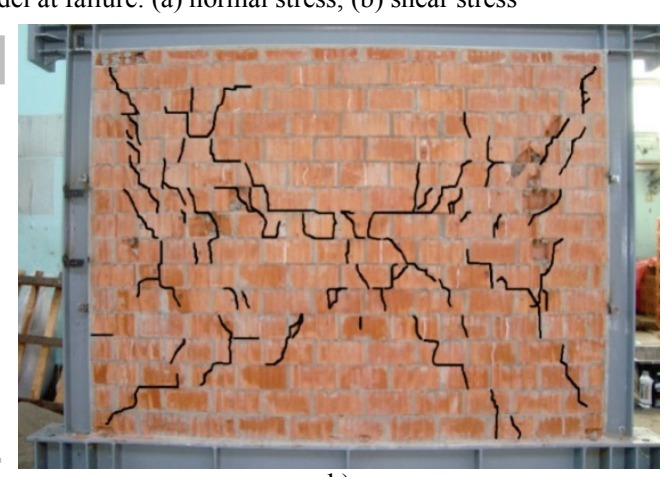

b)

Figure 15 Crack pattern in C-i specimen: (a) analytical solution (b) experimentally obtained

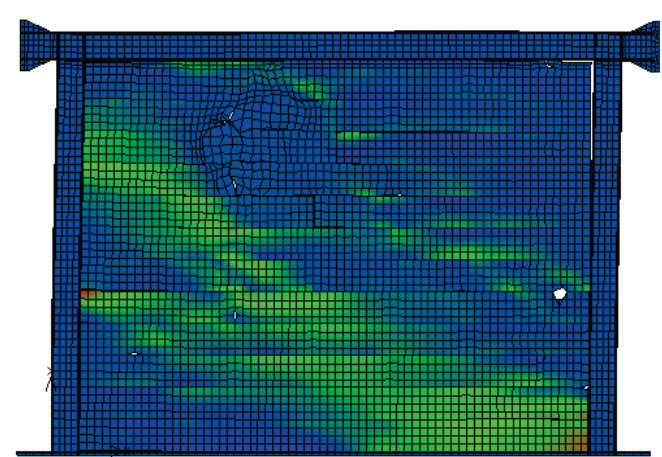

a)

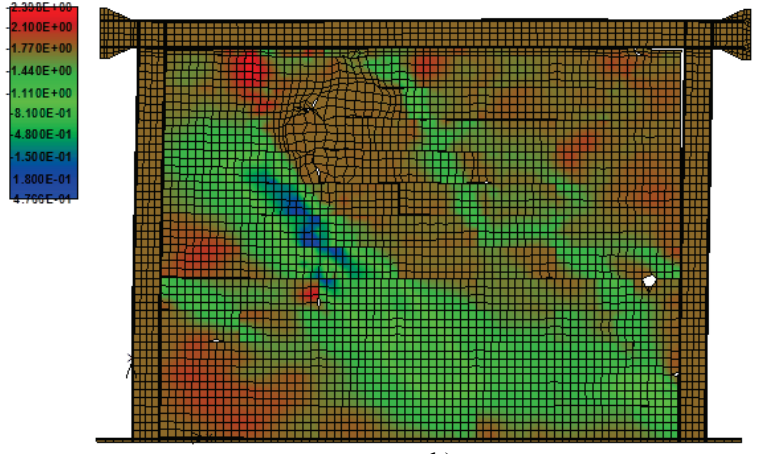

b)

Figure 16 Stress distribution in A-AMM model at 0,5\% interstory drift ratio: (a) normal stress, (b) shear stress 


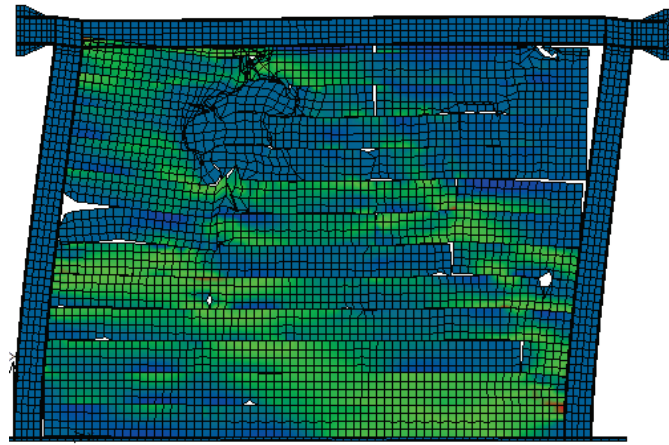

a)

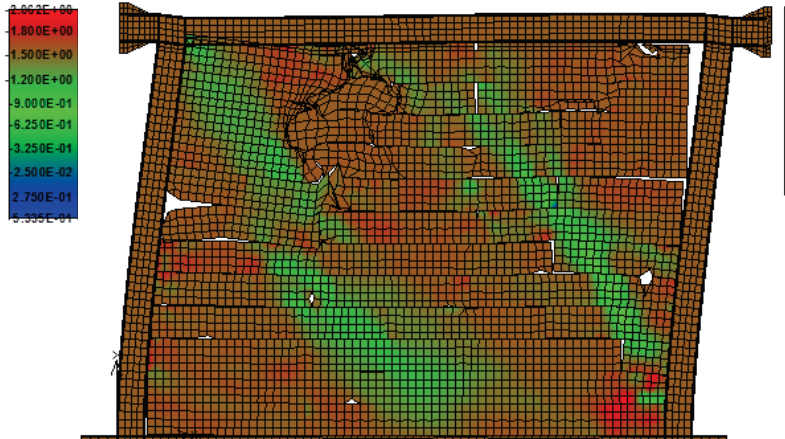

b)

Figure 17 Stress distribution in A-AMM model at failure: (a) normal stress, (b) shear stress

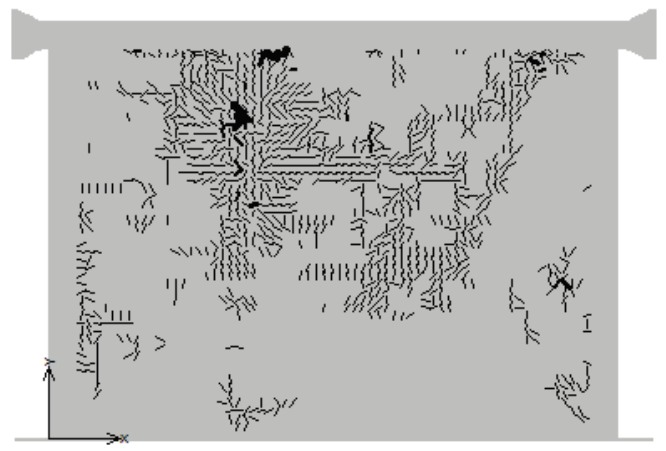

a)



b)

Figure 18 Crack pattern in A-i specimen: (a) analytical solution (b) experimentally obtained



Figure 19 Overview of Initial stiffness and ultimate lateral loads analytical and experimental results for tested specimens

\section{Discussions}

The analytical models commonly used for modelling of the masonry infilled frames, calibrated on the experimentally tested specimens, are presented in the previous sections. At the end of each section the comparisons of analytical and experimental results of the global structural behaviour (e.g. initial stiffness, ultimate lateral load and hysteresis envelopes) of all three tested series have been presented. Compacted form of these results classified by the type of masonry infill $(\mathrm{C}-i, \mathrm{~A}-i)$ is shown in Fig. 19.

The main conclusions regarding several relevant aspects are as following:

\section{(a) Type of the infill}

- differences between the analytical and experimental results for both the initial stiffness and ultimate load are the smallest for specimens infilled with the perforated clay blocks ( $\mathrm{C}-i$ series); among the four analytical models the model with infill-panel macroelement showed a bit greater deviation in prediction of the experimental values, while the single strut model was almost quite accurate;

- behaviour of the specimens with AAC blocks (A- $i$ series) was much harder to predict - the analytical results are spread out over a wider area compared to specimens of C- $i$ series;

- the first two facts can be connected with the experimental observations - while the $\mathrm{C}-i$ specimens behaved regularly, with smooth and very similar hysteretic curves, the behaviour of A- $i$ specimens was quite different due to the ability of holding its integrity well into the inelastic range; a combination of weak units and strong glue possesses significant deformation potential after reaching the particular (critical) value of the shear strength.

\section{(b) Type of the model}

- models with equivalent diagonals (SSM and MSM) were very efficient for predicting the global structural behaviour of frames infilled with common clay infill; in the case of 'weak' infills (A- $i$ specimens) their accuracy was less reliable than other analytical models;

- model with infill-panel macro-element (SPM) was acceptably reliable for all types of infill with noticeably the shortest time required for response calculation. They were also capable to produce the whole hysteresis behaviour of the specimens what makes this model very suitable for engineering practice;

- micro-models (AMM) were the most accurate analytical models used in the analysis - it was 
observed that besides very good prediction of the global behaviour indicators these models were also capable of convincingly tracing the other relevant structural parameters -cracking patterns (Fig. 15 and 18), the primary curves (Fig. 20) and various local effects that can be further checked. However, these models required large number of parameters that ought to be calibrated (where many of them were based on the experimental results) and longer time for calculations.



\section{(c) Local effects}

- change of the bending moments versus inter-storey drift for $\mathrm{C}-i$ series at characteristic frame points (1 to 3 ) is shown in Fig. 21. The obvious fact that single strut model cannot predict local effects on the columns caused by the masonry infill action is visible on the point 2. There was a difference between the values obtained by the MSM and SPM models. It is a consequence of the earlier mentioned fact that masonry macro-element in the SPM model transfers the internal forces to the corner nodes of the frame;

- micro-models were capable to simulate a wide spectra of local effects otherwise hardly available to other model types - e.g. the slip between the frame and the infill, the onset of cracking, influence of the presence of a gap between the frame and the infill, local characteristics of the contact areas etc. These simulations can also be very useful in the calibration process.

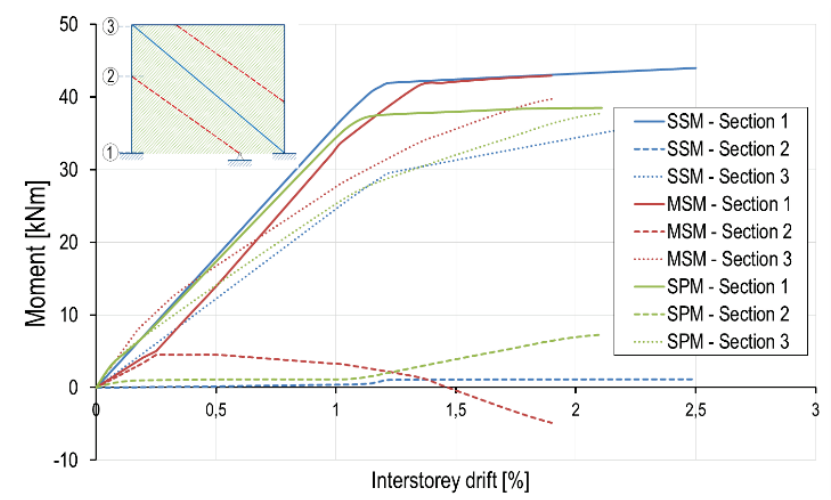

Figure 21 Change of the bending moments at characteristic frame points vs. inter-storey drifts

\section{Conclusions}

The analytical modelling of infilled frames is still very complex due to a great variety of masonry mechanical characteristics, numerous uncertainties regarding the physical behaviour and experimental testing of that combined (interactive) structural system and strong dependence on workmanship conditions. Further research on these structures is justified by the final aim of collecting, analysing, classification and processing of the data in order to create the appropriate design models that can be codified. The probabilistic approach with detailed analysis of the basic variables and other relevant parameters is expected to offer powerful tool for resolving this problem.

In that course, on the basis of previously conducted experimental tests of steel frames infilled with masonry walls, [1], the common analytical models of the tested specimens have been created and calibrated. Three types of macro-models and detailed micro-model were used for modelling of the frames infilled with two types of masonry infill ('strong' clay units and 'weak' AAC units). A total of eight analytical models were analysed with their relevant model characteristics along with the quality of presentation of the measured results and their applicability.

It has been observed that the single strut model (C$\mathrm{SSM}$ ) results were very reliable in the case of clay masonry infilled frames but not so accurate for aerated concrete infilled frames (A-SSM). The same trend goes for the three strut models (C-SSM and A-SSM) but with further reduction of accuracy degree. Still, these models provide a relative quick insight into initial stiffness and lateral load resistance of masonry infilled frames. Thus, they represent an acceptable method for engineering practice where there is neither extensive experimental work nor the acquisition of various often hard to get parameters. On the other hand, the macro-element model predictions were more accurate in the case of aerated concrete infilled frames (A-SPM) than in the case of clay masonry infilled frames (C-SPM). That model better predicted ultimate load capacity than initial stiffness of the system for both analysed types of infill. The strong advantages of the macro-element model are very fast response calculation as well as capability for producing hysteresis behaviour of the analysed system. The micromodel (C-AMM and A-AMM) results coincide with experimentally obtained values for both types of infilled frames and were the best predicted analytical results achieved in this analysis. They were able to provide further exploration of behaviour and failure mechanisms (e.g. delamination of masonry infill from the frame, sliding of masonry elements at mort contact surface, concentration and redistribution of stress in masonry infill at crack initialization, etc.), but at the same time are very complex, computationally demanding, time consuming and still inapplicable for larger structures.

Everything being taken into account, it seems that macro-element models represent a promising platform for further development of accuracy while maintaining their strong advantages compared to the other models used.

In the future work, a parametric analysis of various relevant model parameters with calibrated analytical 
models presented in this paper will be done. These would offer another set of valuable data useful in further comprehension of the analysed structural systems.

\section{Acknowledgments}

The research presented in this full paper is a part of the research project "Seismic design of infilled frames", No. 149-1492966-1536, supported by the Ministry of Science, Education and Sports of the Republic of Croatia and its support is gratefully acknowledged.

\section{References}

[1] Markulak, D.; Radić, I.; Sigmund, V. Cyclic testing of single bay steel frames with various types of masonry infill. // Engineering Structures. 51, 0 (2013), pp. 267-277. DOI: 10.1016/j.engstruct.2013.01.026

[2] European Committee for Standardization (CEN). EN 19981, Eurocode 8: Design of structures for earthquake resistance - Part 1: General rules, seismic actions and rules for buildings. Brussels, Belgium, 2005.

[3] Polyakov, S. V. On the Interactions Between Masonry Filler Walls and Enclosing Frame When Loaded in the Plane of the Wall. // Translations in Earthquake Engineering Research Institute, Moscow, Russia, (1956.), pp. 36-42.

[4] Holmes, M. Steel frames with brickwork and concrete infilling. // Proceedings of the Institution of Civil Engineers. 19, 4(1961), pp. 473-478. DOI: 10.1680/iicep.1961.11305

[5] Stafford-Smith, B. Behavior of square infilled frames. // ASCE Journal of the Structural Division. 92, ST1 (1966), pp. 381-403.

[6] Smith, B. S.; Carter, C. A method of analysis for infilled frames. // Proceedings of the Institution of Civil Engineers. 44, 1 (1969), pp. 31-48.

[7] Mainstone, R. J. Summary of paper 7360 . On the stiffness and strengths of infilled frames. // Proceedings of the Institution of Civil Engineers. 49, 2(1971), pp. 230. DOI: 10.1680/iicep.1971.6267

[8] Dawe, J.; Seah, C. Behaviour of masonry infilled steel frames. // Canadian Journal of Civil Engineering. 16, 6(1989), pp. 865-876. DOI: 10.1139/189-129

[9] Durrani, A. J.; Luo, Y. H. Seismic retrofit of flat-slab buildings with masonry infills. // Proceedings from the NCEER workshop on seismic response of masonry infills / San Francisco, USA, 1994, pp. 1-8.

[10] Zarnic, R.; Tomazevic, M. An experimentally obtained method for evaluation of the behaviour of masonry infilled $\mathrm{R} / \mathrm{C}$ frames. // Proceedings of Ninth World Conference on Earthquake Engineering. (1988), pp. 163-168.

[11] Liauw, T. C.; Kwan, K. H. Nonlinear behaviour of nonintegral infilled frames. // Computers \& Structures. 18, 3(1984), pp. 551-560. DOI: 10.1016/0045-7949(84)90070-1

[12] Paulay, T.; Priestley, M. Seismic design of reinforced concrete and masonry buildings. John Wiley \& Sons, New York, 1992. DOI: 10.1002/9780470172841

[13] Cavaleri, L.; Papia, M. A new dynamic identification technique: application to the evaluation of the equivalent strut for infilled frames. // Engineering Structures. 25, 7(2003), pp. 889-901. DOI: 10.1016/S0141-0296(03)00023-3

[14] Abdul-Kadir, M. R. The structural behaviour of masonry infill panels in framed structures. University of Edinburgh, 1974.

[15] Markulak, D.; Sigmund, V.; Radić, I. Modeliranje čeličnih okvira sa zidanim ispunom. // Građevinar. 60, 4(2008.), pp. 317-326.
[16] Leuchars, J.; Scrivener, J. Masonry infill panels subjected to cyclic in-plane loading. // Bulletin of the New Zealand National Society for Earthquake Engineering. 9, 2(1976), pp. 122-131.

[17] Thiruvengadam, V. On the natural frequencies of infilled frames. // Earthquake Engineering \& Structural Dynamics. 13, 3(1985), pp. 401-419. DOI: 10.1002/eqe.4290130310

[18] Syrmakezis, C.; Vratsanou, V. Influence of infill walls to RC frames Response. // Proceedings of the Eighth European Conference on Earthquake Engineering / Istanbul, Turkey, 1986, pp. 47-53.

[19] Chrysostomou, C. Z.; Gergely, P.; Abel, J. F. Nonlinear seismic response of infilled steel frames. // Proceedings of Tenth world conference on earthquake engineering / Madrid, Spain, 1992, pp. 4435-4442.

[20] Saneinejad, A.; Hobbs, B. Inelastic Design of Infilled Frames. // Journal of Structural Engineering. 121, 4(1995), pp. 634-650. DOI: 10.1061/(ASCE)0733-9445(1995)121:4(634)

[21] El-Dakhakhni, W.; Elgaaly, M.; Hamid, A. Three-Strut Model for Concrete Masonry-Infilled Steel Frames. // Journal of Structural Engineering. 129, 2(2003), pp. 177 185. DOI: 10.1061/(ASCE)0733-9445(2003)129:2(177)

[22] Mallick, D. V.; Severn, R. T. The behaviour of infilled frames under static loading. // Proceedings of the Institution of Civil Engineers. 38, 4(1967), pp. 639-656. DOI: 10.1680/iicep.1967.8192

[23] Riddington, J. R.; Smith, B. S. Analysis of infilled frames subject to racking with design recommendation. // Structural Engineer. 55, 6(1977.), pp. 263-268.

[24] King, G. J. W.; Pandey, P. C. The analysis of infilled frames using finite elements. // Proceedings of the Institution of Civil Engineers. 65, 4(1978), pp. 749-760. DOI: 10.1680/iicep.1978.2707

[25] Dhanasekhar, M.; Page, A. The influence of brick masonry infill properties on the behaviour of infilled frames. // Proceedings of the Institution of Civil Engineers. 81, 4(1986), pp. 593-605.

[26] El Haddad, M. H. Finite element analysis of infilled frames considering cracking and separation phenomena. // Computers \& Structures. 41, 3(1991), pp. 439-447. DOI: 10.1016/0045-7949(91)90136-A

[27] Mehrabi, A. B.; Shing, P.; Schuller, M.; Noland, J. Performance of masonry-infilled $\mathrm{R} / \mathrm{C}$ frames under in-plane lateral loads. University of Colorado, Department of Civil, Environmental \& Architectural Engineering, 1994.

[28] Koutromanos, I.; Stavridis, A.; Shing, P. B.; Willam, K. Numerical modeling of masonry-infilled RC frames subjected to seismic loads. // Computers \& Structures. 89, 11-12(2011), pp. 1026-1037. DOI: 10.1016/j.compstruc.2011.01.006

[29] Mohyeddin, A.; Goldsworthy, H. M.; Gad, E. F. FE modelling of RC frames with masonry infill panels under in-plane and out-of-plane loading. // Engineering Structures. 51, 0(2013), pp. 73-87. DOI: 10.1016/j.engstruct.2013.01.012

[30] Asteris, P. G.; Cotsovos, D. M.; Chrysostomou, C. Z.; Mohebkhah, A.; Al-Chaar, G. K. Mathematical micromodeling of infilled frames: State of the art. // Engineering Structures. 56, 0(2013), pp. 1905-1921. DOI: 10.1016/j.engstruct.2013.08.010

[31] Autodesk. Autodesk Robot Structural Analysis - Metric Getting Started Guide. 2010. http://images.autodesk.com/ adsk/files/robot_getting_started_guide_eng_2011_metric_2 .pdf.

[32] FEMA 306 - NHERP Evaluation of Earthquake Damaged Concrete and Masonry Wall Buildings. Federal Emergency Management Agency, Applied Technology Council, Washington DC, United States, 1998.

[33] Celarec, D.; Ricci, P.; Dolšek, M. The sensitivity of seismic response parameters to the uncertain modelling variables of 
masonry-infilled reinforced concrete frames. // Engineering Structures. $\quad 35, \quad 0(2012), \quad$ pp. 165-177. DOl: 10.1016/j.engstruct.2011.11.007

[34] Degefa, M. Response of masonry infilled rc frame under horizontal seismic force. Addis Ababa University, 2005.

[35] Saliklis, E. P.; Tokyay, B. Empirical Prediction of Shear Modulus and Young's Modulus of Plywood Panels. // Architectural Engineering, (2000), pp. 32

[36] Seismosoft "SeismoStruct v7.0 - A computer program for static and dynamic nonlinear analysis of framed vstructures". (2014), http://www.seismosoft.com

[37] Crisafulli, F. J.; Carr, A. J. Proposed macro-model for the analysis of infilled frame structures. // Bulletin of the New Zealand Society for Earthquake Engineering. 40, 2(2007), pp. 69-77

[38] Crisafulli, F. J. Seismic behaviour of reinforced concrete structures with masonry infills. University of Canterbury, 1997

[39] Červenka, V.; Jendele, L.; Červenka, J. ATENA Program Documentation - Part 1 - Theory Cervenka Consulting. $2014 . \quad \mathrm{http}: / / \mathrm{www} . c e r v e n k a . c z / a s s e t s /$ files/atena-pdf/ ATENA Theory.pdf. (20.05.2015)

[40] Červenka, V.; Červenka, J. ATENA Program Documentation - Part 2-1 - User's Manual for ATENA 2. Cervenka Consulting. 2015. http://www.cervenka.cz/ products/atena/documentation/pdf-users-manual-for-atena2d. (20.05.2015)

\section{Authors' addresses}

doc. dr. sc. Ivan Radić, dipl. ing. grad. Josip Juraj Strossmayer Univerisity of Osijek, Faculty of Civil Engineering, Crkvena 21, 31000 Osijek, Croatia

E-mail: radic@gfos.hr

prof. dr. sc. Damir Markulak, dipl. ing. grad. Josip Juraj Strossmayer Univerisity of Osijek, Faculty of Civil Engineering,

Crkvena 21, 31000 Osijek, Croatia

E-mail: markulak@gfos.hr

prof. dr. sc. Vladimir Sigmund, dipl. ing. grad Josip Juraj Strossmayer Univerisity of Osijek,

Faculty of Civil Engineering,

Crkvena 21, 31000 Osijek, Croatia

E-mail: sigmund@gfos.hr 